\title{
Climate hotspots: key vulnerable regions, climate change and limits to warming
}

\author{
William L. Hare · Wolfgang Cramer • \\ Michiel Schaeffer • Antonella Battaglini • \\ Carlo C. Jaeger
}

Published online: 4 January 2011

(C) Springer-Verlag 2010

\begin{abstract}
Defining and operationalizing Article 2 of the UNFCCC remains a challenge. The question of what is dangerous climate change is not a purely scientific one, as danger necessarily has a subjective dimension and its definition requires judgment and precaution. The papers in this special issue of Regional Environmental Change attempt to navigate this problem, by offering an overview of the latest scientific findings in the context of risks and uncertainties, and assess some key vulnerabilities that might lead to dangerous climate change. This synthesis provides an overview of the papers in this issue and looks at four areas of possible dangerous climate changeadverse declines in regional food and water security, loss of arctic sea ice with projected extinction of species, largescale sea-level rise and loss of coral reef systems. These issues affect a number of different regions including Africa, South Asia, and Small Island Developing States. Significant risks to vulnerable regions and systems at warming levels of $1.5-2^{\circ} \mathrm{C}$ above pre-industrial are identified. The direct effects of $\mathrm{CO}_{2}$ concentration increases in
\end{abstract}

W. L. Hare · W. Cramer $(\bowtie)$

Earth System Analysis, Potsdam Institute for Climate

Impact Research, Telegraphenberg A62, PO Box 6012 03,

14412 Potsdam, Germany

e-mail: Wolfgang.Cramer@pik-potsdam.de

W. L. Hare · M. Schaeffer

Climate Analytics, Potsdam, Germany

M. Schaeffer

Environmental Systems Analysis Group, Wageningen University and Research Centre, Wageningen, The Netherlands

A. Battaglini - C. C. Jaeger

Transdisciplinary Concepts and Methods, Potsdam Institute for Climate Impact Research, Potsdam, Germany terms of ocean acidification are identified as relevant to Article 2 because of the risks posed to coral reefs. Ultimate $\mathrm{CO}_{2}$ stabilization levels that allow for the long-term viability of coral reefs likely are below $350 \mathrm{ppm}$. The paper concludes by arguing that the emission reduction pledges made by countries under the Copenhagen Accord will not suffice to prevent dangerous climate change.

Keywords Climate change impacts - Warming levels · Dangerous climate change

\section{Introduction}

The papers in this special issue of Regional Environmental Change address the question of what may be dangerous levels of climate change: the papers describe and analyse the vulnerability of human and natural systems in a number of regions around the world. The question of what is dangerous clearly relates to values and judgements about risk, and so is not a purely scientific one according to a widespread view of science. However, it is not a purely normative question either: it requires the ability and willingness to navigate the landscape between the two poles of pure factual description and pure normative evaluation. Scientists are often reluctant to express judgements, but in the papers collected in this special issue, after presenting scientific results, the authors have applied their own criteria and judgements for reaching what they see as reasonable conclusions. In some cases, authors have indicated changes that they consider to be dangerous, in others they have pointed to risks, vulnerabilities and uncertainties, which preclude in their view reaching conclusions at this point. Decisions are often made under uncertainty and based on perception and personal judgements. For this reasons, we 
believe that the articles in this special issues provide a necessary overview of what might be considered as dangerous climate change.

Climate change is a global challenge. Scientific evidence has often failed to translate into stringent and effective policies. Investments in clean technologies and in adaptation are considered costs to society and often opposed to the need to safeguard the economy. Short-term criteria are usually applied to measure success in our societies, and we systematically fail to realize that investments in transforming our economies are not costs, but rather, indeed investments in the future.

In this context, it is important to address the questions raised by Article 2 and try to define what dangerous climate change might be. Article 2 calls for a judgement, based on experience, scientific results and, when necessary, the precautionary principle. Scientists, policy makers and society at large need to take decisions and to act to prevent danger from becoming disaster.

In this paper, we review the context of what is dangerous climate change under the terms of the United Nations Framework Convention on Climate Change (UNFCCC), we look at some of the issues involved in deciding what might be dangerous and why one would wish to make such a determination, and then attempt to draw some lessons for future consideration of the question by the scientific and policy community.

\section{Preventing dangerous anthropogenic interference with the climate system}

Article 2 of the UNFCCC has a far reaching and broad ultimate goal (for a review of its origins see Oppenheimer and Petsonk 2005). It requires that the Parties to the Convention, essentially the entire world community, work together to prevent dangerous interference with the climate system. In full, Article 2 states that:

"The ultimate objective of this Convention and any related legal instruments that the Conference of the Parties may adopt is to achieve, in accordance with the relevant provisions of the Convention, stabilization of greenhouse gas concentrations in the atmosphere at a level that would prevent dangerous anthropogenic interference with the climate system. Such a level should be achieved within a time frame sufficient to allow ecosystems to adapt naturally to climate change, to ensure that food production is not threatened and to enable economic development to proceed in a sustainable manner." (UNFCCC 1992).

Article 2 has several interrelated elements and which are themselves linked to other parts of the Convention:
- Stabilization of greenhouse gas concentrations in the atmosphere

- Prevent dangerous anthropogenic interference with the climate system

- Within a time frame sufficient to:

- Allow ecosystems to adapt naturally to climate change,

- Ensure that food production is not threatened

- Enable economic development to proceed in a sustainable manner.

Stabilization of greenhouse gas concentrations is specifically linked to levels that would "prevent dangerous interference with the climate system", and these levels are to be achieved "within a time frame" sufficient for criteria (ecosystems, food production and economic development) to be met (Verheyen 2007). There is no specific reference to a particular timeframe by which this stabilization should be achieved, nor its manner, and this is open to be decided based on the criteria in Article 2. It is open, for example as to whether, concentrations would rise above an ultimate stabilization level, before falling back, providing that in the end anthropogenic interference with the climate system is prevented.

Legally, it has been argued that Article 2 represents a prevention duty with consequential legal obligations that limits discretion for interpreting the term "dangerous" and that carries with it an obligation to take specific action to achieve this goal, including negotiating specific commitments to reduce greenhouse gas emissions (Verheyen 2007).

The term "dangerous" is important for the interpretation of Article 2. The ordinary meaning of the word is that if something is able, or likely, to inflict injury or harm, or involves exposure to danger, then it is dangerous. A "dangerous" interference with the climate system then must be something that may cause harm or loss. Article 2 demands a judgment as to whether something is likely to cause harm or loss and how significant this may be. A change in the state of the climate system is not in itself dangerous, but its consequences may be.

What is important in the context of the UNFCCC is that specific groups of countries are recognized as most vulnerable, and legally this implies that any definition of the term 'dangerous interference' needs to be oriented towards these countries and not necessarily towards the most resilient countries and regions (Verheyen 2007). Amongst the regions recognized as the most vulnerable are the small island developing states, least developed countries and mountain regions.

The term "dangerous anthropogenic interference" (DAI) is not limited to short-term risks, but also to levels of climate change that may trigger highly adverse changes to 
components of the climate system that could take centuries to millennia to be fully felt. Examples include levels of warming that may not pose immediate threats, but in the future could result in the partial or complete loss of the Greenland and/or West Antarctic ice sheets, or cross other tipping point thresholds (Kriegler et al. 2009; Lenton et al. 2009; Malhi et al. 2009).

Apart from global warming itself, dangerous anthropogenic interference with the climate system ${ }^{1}$ could occur as a result of increases in carbon dioxide $\left(\mathrm{CO}_{2}\right)$ concentration causing ocean acidification (Orr et al. 2005), with the level of acidification largely independent of climate changes induced by elevated GHG concentrations (Cao et al. 2007; McNeil and Matear 2007). Ocean acidification adversely affects a basic aspect of the climate system and has consequences for ecosystems and human food production dependent upon marine organisms. Of current anthropogenic $\mathrm{CO}_{2}$ emissions, about $30 \%$ is absorbed by the oceans, in response to the higher $\mathrm{CO}_{2}$ concentration of the atmosphere (Denman et al. 2007). The acidity of the ocean waters rises when additional $\mathrm{CO}_{2}$ is absorbed. The increase in atmospheric $\mathrm{CO}_{2}$ concentration from $278 \mathrm{ppm}$ in the pre-industrial period to over $387 \mathrm{ppm}$ in 2009 has led to an increase in the ocean's acidity, estimated at a reduction of 0.1 units of $\mathrm{pH}$ since pre-industrial (Meehl et al. 2007).

Increasing ocean acidity poses a threat to many marine species and ecosystems and their productivity (Bates et al. 2009; Comeau et al. 2009; Feely et al. 2009; McClintock et al. 2009; Moy et al. 2009; Crawley et al. 2010; Manzello 2010; Shi et al. 2010), although uncertainties persist (Hendriks et al. 2010). It has become clear in the last few years that the onset of serious consequences of ocean acidification on marine may be contemporaneous with serious warming induced consequences on the same systems and species. Hoegh-Guldberg (2010) points towards serious and contemporaneous pressure on coral reefs from both acidification and warming: others have indicated serious risks for Arctic and Antarctic systems within several decades (McNeil and Matear 2008; Steinacher et al. 2009; McNeil et al. 2010).

The three broad themes highlighted in Article 2-ecosystems, food production, sustainable economic development-provide some guidance as to its interpretation. Greenhouse gas concentrations must be stabilized in such a way and within a timeframe that ecosystems can adapt naturally, food production is not threatened and that economic development is able to proceed in a sustainable manner.

\footnotetext{
${ }^{1}$ UNFCCC Article 1.1 defines the climate system quite broadly as "the totality of the atmosphere, hydrosphere, biosphere and geosphere and their interactions".
}

Defining what it means for ecosystems to adapt naturally is quite difficult and may be best approached by examining the effects of climate change on key ecosystem properties, services and values. Substantial loss of, or damage to, properties such as biodiversity including conservation of species, food production and provision of livelihoods, may be relevant measures of ecosystem response to climate change. Large changes in the spatial extent and geographical location of ecosystems could be other measures.

Midgley and Thuiller (2010) provide an example from southern Africa of large-scale projected damages to ecosystem values. With about a $2^{\circ} \mathrm{C}$ warming they predict for the endemic flora of southern Africa an average reduction by about $40 \%$ in habitat-specific species richness. For a higher warming of $3-3.5^{\circ} \mathrm{C}$, projections for 5,197 African plant species show that $25-42 \%$ could lose all suitable range by 2085. For Australia, Hughes (2010) shows quite high risks for warming in the range of $1.5-2^{\circ} \mathrm{C}$ for the Australian Alpine region, the Great Barrier Reef, World Heritage rainforests and wetlands. In Europe, Alkemade et al. (2010) show an increasing and substantial risk of extinction with increasing warming, so that by around $3{ }^{\circ} \mathrm{C}$ warming, $25 \%$ of the species are projected to disappear from Mediterranean Europe and Northern European ecosystems are transformed with $35 \%$ of species there newly introduced.

Ni (2010) has looked at ecosystem changes in China and shows that large and rapid movements in ecosystems are projected. The loss of grasslands, high elevation meadows and steppe in particular could lead to losses of biological diversity. The Tibetan Plateau is one of the more sensitive regions containing many unique environments that are very sensitive and vulnerable to climate change and human disturbances. Warming of this region will accelerate the loss of permafrost and thereby contribute to the process of desertification (Ni et al. 2000). Meadows on the plateau would be reduced in extent (Zhao et al. 2002). Studies on the effects of warming and grazing on high elevation meadows indicate that these pressures could cause large, rapid declines in plant species diversity (Klein et al. 2004).

The requirement to ensure that food production is not threatened might appear straightforward; however, the question of regional differences is paramount. Global increases in food production could, for example, be accompanied by reductions at regional levels whose consequences for food security would depend upon the regional context and the socio-economic scenarios assumed both globally and regionally. Is a large regional reduction in food security dangerous under the meaning of Article 2, even whilst globally food production may increase? Assume for example that Indian food production is reduced under warming, as suggested by Lal (2010). 
Indians might feel that this would be dangerous and an infringement on their right to development. Elsewhere, however, in regions where crop production has, or is projected to increase, there may be feeling that this is in fact an opportunity for greater exports, or at the least food deficits could be dealt via food aid programmes, in other words by compensation rather than by prevention.

Tao et al. (2010) explore risks for food production in China and in overall terms find that there is insufficient work available to define whether the risks could be dangerous for agricultural production in China, with some likelihood of improved conditions. In common with many other studies of this region, this work shows the importance of the strength of the $\mathrm{CO}_{2}$ fertilization effect, which remains uncertain. Most studies show little adverse effects in China's food production if $\mathrm{CO}_{2}$ fertilization works as projected, but significant reductions if not (Xiong et al. 2007a, b; Yao et al. 2007; Tao et al. 2009; Tao and Zhang in press).

Unmitigated climate changes is projected to threaten sustainable economic development in a number of regions, causing significant problems in areas as diverse as health, water supply, agriculture, infrastructure damages and financial and other economic services (IPCC 2007). Barnett (2010) in his paper argues that the projected adverse impacts on the economic development of small islands is dangerous. Direct threats to communities in mountain regions were identified by Chevallier et al. (2010) for the Andes and Shrestha and Aryal (2010) for the Himalayas. Both papers provide a striking overview of glacial retreat, causing an enhanced risk of glacial lake outbursts and reducing water security during dry seasons. These changes threaten livelihoods directly through increased natural hazards and indirectly due to negative economic impacts on water security and hydro-energy potential. Effective mitigation of climate change may be a prerequisite for sustainable economic development in many regions whilst delayed mitigation and higher levels of climate change could lead not only to increased costs, but also hamper sustainable development.

Beyond these three criteria, however, Crowley (2010) has argued that climate change will lead to human rights violations specifically in relation to the Inuit people of the Arctic and that this requires consideration by parties under the terms of Article 2 of the UNFCCC. Kittel et al. (2010) provide an insight into the profound changes in the Alaskan landscape and ecosystems that have been observed in the past 50 years, including by the Inuit people, driven by warming, permafrost thaw and sea-ice thinning and that are projected to accelerate the future. Whilst legally unclear in the context of the UNFCCC, the impacts of climate change on indigenous people and communities, particularly in polar and mountain regions was recognized as a key vulnerability in the IPCC AR4 assessment.

\section{Why is defining the ultimate objective of climate policy important?}

The large inertia in parts of the climate system and in socioeconomic systems implies the need, long recognized, for decision-making on levels of mitigation far ahead of the time at which full certainty on the impacts of climate change would be achieved (Nordhaus 1977). It is therefore necessary to decide on the climate risks that are to be minimized or prevented in order to be able to actively manage other unavoidable emerging risks. Not deciding on what levels of risks to take, could in effect, be deciding to take higher risks given that large amounts of warming and sea-level rise would be irreversibly committed from emissions that might otherwise have been avoided (Friedlingstein and Solomon 2005; Wigley 2005; Hare and Meinshausen 2006; Donner 2009). Following from this is the need to have quantitative guidance on emission pathways that are consistent with limiting risks, and hence on the required mitigation and adaptation tasks that need to be planned for. Decisions made in relation to Article 2 (or not made) would determine the level of climate change that is set as the goal for policy (or which is committed to as a consequence of lack of action), and these decisions have fundamental implications for emission reduction pathways and technological requirements as well as the scale of adaptation required.

\section{The history of Article 2: attempts to define dangerous interference $^{2}$}

In 1985 at a meeting in Villach, Austria ${ }^{3}$ an international gathering of scientists raised essentially for the first time the concern that projected human induced climate change would lead to unacceptable damages and changes to the earth, its ecosystems and to humans and human society. Since that time, several scientific assessment groups have sought to identify acceptable or tolerable limits to human induced climate change. There have been two broad approaches, often combined. One is based on a risk assessment using projected impacts of climate change on ecosystems, agriculture and other sectors. The other is based on a safe climate analogue approach which focuses on avoiding greater changes than are thought to have occurred in recent earth history (e.g., the current and the last few interglacial periods extending back half a million years or so). In this latter approach, the core idea is that tolerable human-induced changes are limited to those that would maintain the climate system within or close to a

\footnotetext{
${ }^{2}$ For the theme of this section see also the contribution of Jaeger and Jaeger (2010).

${ }^{3}$ http://www.icsu-scope.org/downloadpubs/scope29/statement.html.
} 
state in terms of greenhouse gas concentrations which is not very different than the present interglacial and away from states associated with large or rapid changes in climate and/or components of the climate system such as the present ice sheets of Greenland and Antarctica.

One of the earliest attempts dating from the late 1980s to define acceptable limits to warming is that of the German Enquetekommission, a joint committee of Parliamentarians and scientists which set as a limit $0.1^{\circ} \mathrm{C}$ per decade as a level especially critical to forest ecosystems with an overall maximum warming of 1 or $2^{\circ} \mathrm{C}$ (Jain and Bach 1994).

One of the most important contributions was that of the UNEP/WMO/ICSU United Nations Advisory Group on Greenhouse Gases (AGGG) which was established in 1986 (Potter 1986). It reviewed the early climate impacts literature as well as what was known at that time about the behaviour of the climate system in the past. In its report in 1990, the AGGG combined both approaches to identify two main temperature indicators or thresholds with different levels of risk (Rijsberman and Swart 1990). The AGGG found that an increase of greater than $1{ }^{\circ} \mathrm{C}$ above pre-industrial climate levels "may elicit rapid, unpredictable and non-linear responses that could lead to extensive ecosystem damage" and that warming rates above $0.1^{\circ} \mathrm{C} /$ decade were likely to lead to rapidly increasing risk of significant ecosystem damage. A $2^{\circ} \mathrm{C}$ increase was suggested by the AGGG to be "an upper limit beyond which the risks of grave damage to ecosystems, and of non-linear responses, are expected to increase rapidly". On sea-level rise, the AGGG argued that rates of sea-level rise of less than $20 \mathrm{~mm} /$ decade $(20 \mathrm{~cm} /$ century) "would permit the vast majority of vulnerable ecosystems, such as natural wetlands and coral reefs to adapt with rates beyond this leading to rapidly rising ecosystem damage" and limiting total sea-level rise to a $50 \mathrm{~cm}$ increase above 1990 global mean sea level could "prevent the complete destruction of island nations, but would entail large increases in the societal and ecological damage caused by storms".

In the mid-1990s, the German Global Change Advisory Council (WBGU) determined an upper limit or "tolerable window" of warming based on a "top down" line of reasoning. It arrived at similar limit to the AGGG setting the tolerable warming limit of a $2^{\circ} \mathrm{C}$ increase relative to preindustrial temperatures (WBGU 1995). Similar to the AGGG, it argued that above this limit there was a risk of "dramatic changes in the composition and function of today's ecosystems". This group confirmed this tolerable limit level in a subsequent assessment in 2003 which considered the question from a bottom up perspective based on a review of projected impacts (WBGU 2003). It was found that above $2{ }^{\circ} \mathrm{C}$ the losses to species and ecosystems were "unacceptable" and that "above this global warming level worldwide climate-related losses in agricultural production must be expected", with "a steep rise in the number of people threatened by water scarcity." Ice sheet instability with consequential multi-metre sea-level rise was identified as a significant risk. It was recognized that "for some regions the effects of climate change would already lead to intolerable impacts at $2{ }^{\circ} \mathrm{C}$ mean global warming". More recently, the $\mathrm{WBGU}$, in the context of a review on the world's oceans, reconfirmed these goals and extended its tolerable limits, or guard rails, to sea-level rise where it recommended a long-term limit of $1 \mathrm{~m}$ with a maximum rate of $5 \mathrm{~cm}$ per decade, as "(o)therwise there is a high probability that human society and natural ecosystems will suffer unacceptable damage and loss" (WBGU 2006).

A group of largely US-based scientists (Hansen et al. 2007; Hansen et al. 2008) have also investigated the issue of what might be dangerous climate changes, whilst acknowledging that identification of this "is partly subjective". Several areas of risk were focused on-Increasing aridity in a number of regions (southern USA, parts of Africa, the Mediterranean basin and Australia), the stability of the ice sheets and long-term sea-level rise, Arctic sea-ice loss and warming, coral reefs, more intense tropical storms with increasing warming, and the likelihood of positive feedbacks amplifying warming due to the release of methane hydrates from the sea bed (which would add methane to the atmosphere, increasing the warming). Considering these issues they find that global warming of more than $1^{\circ} \mathrm{C}$ above 2000 "has effects that may be highly disruptive". This temperature limit with respect to 2000 translates into warming above pre-industrial of below $1.6-1.7^{\circ} \mathrm{C}$, significantly lower than the $2^{\circ} \mathrm{C}$ "tolerable" limit identified by the WBGU. They indicated $\mathrm{CO}_{2}$ levels need to be reduced to "at most 350 ppm, but likely less than that" and warned that if the over shoot of this level "is not brief, there is a possibility of seeding irreversible catastrophic effects". More recent research on the long-term response of ice sheets to warming and coral reefs tends to support at least these elements of the findings of Hansen and colleagues.

It is striking that the science-based assessments of what may be acceptable levels of human induced climate change have remained fairly stable over the last 20 years when expressed in terms of a global temperature limit. Different groups of scientists have successively found that between $1^{\circ}$ and $2^{\circ} \mathrm{C}$ global mean warming above pre-industrial risks rise substantially, to the point where a level of nonacceptability is reached at close too or even below $2^{\circ} \mathrm{C}$ warming. In many respects, each assessment has confirmed the broad picture of risks first identified in 1990 by the UNEP/WMO/ICSU AGGG.

Over the last 20 years, the Intergovernmental Panel on Climate Change has provided four full assessment reports as well as a number of supplementary and special assessments on specific issues on the area of climate change. By its 
mandate, the IPCC does not produce recommendations on what may or may not be acceptable levels of human induced climate change, as it is required to produce policy relevant but not policy prescriptive assessments. These reports have nevertheless been vital inputs into governmental processes considering climate issues since 1990.

In 1996, the European Union, based on a consideration of the IPCC Second Assessment Report (SAR) which was adopted in 1995 (IPCC 1996), agreed a global goal of ensuring that temperatures do not exceed $2^{\circ} \mathrm{C}$ increase above pre-industrial (European Community 1996). This was reconfirmed by the EU Environment Council in 2005 (Environment Council of the European Union 2005) following consideration of the IPCC Third Assessment Report of 2001, and subsequently adopted by the 25 heads of government of the European Union (ENDS 2005; European Union 2005). The so-called $2{ }^{\circ} \mathrm{C}$ goal became one of the planks of the European Union's domestic and international policy, guiding both domestic reduction plans and international diplomatic efforts. In the lead up to the Copenhagen negotiations in 2009 , the $2^{\circ} \mathrm{C}$ goal was adopted by the Major Economies Forum as well as by the G8 leaders meeting in that year (G8 2009; Major Economies Forum 2009).

The conclusion of the IPCC AR4 in 2007 spurred consideration by the small island states and other vulnerable countries of the merits of the EU's $2^{\circ} \mathrm{C}$ goal, as for these countries the AR4 had indicated substantial risk at lower levels of warming. Influenced by this assessment, and a number of the publications by scientific groups mentioned above, as well as growing evidence of impacts, in 2008 the Alliance of Small Island States (AOSIS) began calling for global temperature to be limited to below $1.5^{\circ}$ increase above pre-industrial levels and the $\mathrm{CO}_{2}$ concentrations to be brought below $350 \mathrm{ppm}$ as fast as possible. AOSIS argued that the $\mathrm{EU} 2{ }^{\circ} \mathrm{C}$ goal was unacceptable due to the damage that would be delivered to small island states at this level of warming. In the course of 2009, the least developed country group and others also began calling for warming to be limited to below a $1.5^{\circ} \mathrm{C}$ increase above preindustrial based on similar considerations. By the time of UNFCCC Conference of the Parties (COP15) in Copenhagen, December 2009 a total of 101 countries, accounting for 5\% of global energy and industry related $\mathrm{CO}_{2}$ emissions and about $23 \%$ of global population in $2005^{4}$ were calling for this goal to be adopted.

\footnotetext{
4 Those countries calling for global temperature to stay below $2^{\circ} \mathrm{C}$ comprise together a total of 46 countries, accounting for $83 \%$ of global energy and industry related $\mathrm{CO}_{2}$ and about $65 \%$ of global population in 2005 Sources: Emissions-PRIMAP Baseline Reference: PRIMAP3 (2009) Potsdam Real-time Integrated Model for probabilistic Assessment of emissions Paths (PRIMAP), http://www.primap.org. Population-UN (2008) 'World Population Prospects: The 2008 Revision Population Database', http://esa.un.org/unpp.
}

Both of these goals were reflected in the Copenhagen Accord, which was negotiated as part of a closed negotiating segment by 26 nations mostly at head of government level at COP15 and hence only 'taken note of' by the Conference of Parties. The Accord agreed "that deep cuts in global emissions are required according to science, $[\ldots]$ with a view to reduce global emissions so as to hold the increase in global temperature below 2 degrees Celsius ${ }^{5}$ " and hereby preventing "dangerous anthropogenic interference with the climate system". The goal of limiting warming to $1.5^{\circ} \mathrm{C}$ is referenced in association with potentially strengthening the $2^{\circ} \mathrm{C}$ long-term temperature goal based on "various matters presented by the science" in 2015. As of November 2010, a total of 140 countries have expressed their intention to be listed as "agreeing" with the Accord. ${ }^{6}$

Although the Copenhagen Accord is not a legal agreement as such, it does represent an important political interpretation at head of government level of the meaning of Article 2 of the climate change convention. It was concluded at Head of Government level and it specifically references the objective of preventing dangerous interference with the climate system. It is also clear that the emission pledges made by Parties to date under the Accord are not consistent with the $2^{\circ}$ or $1.5^{\circ} \mathrm{C}$ goals (Rogelj et al. 2010a, b).

\section{New findings relevant to Article 2}

The papers in this special issue all tend to confirm the picture of regional risks and vulnerabilities in a range of regions and systems around the world as reported in the IPCC Fourth Assessment Report. There are several new developments, however, which will be highlighted here.

\section{Food production}

In relation to food production, the papers in this volume confirm earlier studies showing that climate change will induce strong contrasts between world regions, by causing yield increases in some and decreases in others, to an extent that is not easily solved by international markets (e.g., Battisti and Naylor 2009; Penny et al. 2010). Significant risks to food and water security are indicated for

\footnotetext{
5 The Copenhagen Accord does not reference these increases to preindustrial or any other base year or period. The interpretation applied here is that this is a drafting oversight as there was no other target on the table apart from the $2^{\circ}$ and $1.5^{\circ} \mathrm{C}$ increases above pre-industrial and there is no evidence that the pre-industrial reference period was removed for any specific reason or at the request of any party.

${ }^{6}$ http://unfccc.int/home/items/5262.php accessed 18 November 2010.
} 
South Asia (Lal 2010; Mirza 2010), Sahelian and northern Africa (Sissoko et al. 2010), Ben Mohamed (2010), Mougou et al. (2010), Iglesias et al. (2010) and parts of Russia (Dronin and Kirilenko 2010) by the time global mean warming reaches around $2^{\circ} \mathrm{C}$ above preindustrial.

Lal (2010) shows that India needs to increase its production by $1.5 \%$ per year to feed its developing and growing population, faster than historical experience, but faces likely net cereal production losses in South Asia due to climate change of $4-10 \%$ for a $2^{\circ} \mathrm{C}$ warming. Lal (2010) further argues that warming above $3^{\circ} \mathrm{C}$ could have catastrophic consequences. Mirza (2010) shows a rapidly increasing risk for Bangladesh as warming rises towards $2{ }^{\circ} \mathrm{C}$, due to flooding, with losses plateauing as flooded area stabilizes, at a time that Bangladesh is projected to need to increase grain production by $3 \%$ per year (historically $2 \%$ / year).

In contrast to European Mediterranean countries that are expected to be able to cope with drought trends in the larger context of EU agricultural policy (Bindi and Olesen 2010), Iglesias et al. (2010) lay bare the very low adaptive capacity of African Mediterranean countries that will be confronted with increased drought and associated yield reductions. In the Sahel region, Sissoko et al. (2010) explain how existing coping strategies may break down under the pressures of future development in the context of yield decreases, confirmed by Ben Mohamed (2010), who report a projected loss in yields of millet, a major staple crop in the region, of $20 \%$ around $2^{\circ} \mathrm{C}$ warming, rising to $40 \%$ at about $3^{\circ} \mathrm{C}$. The picture for parts of the African region covered in this issue is consistent with recent reviews, which indicate quite large negative impacts on food production at levels of warming lower than $2^{\circ} \mathrm{C}$ above pre-industrial (Burke et al. 2009; Schlenker and Lobell 2010). As discussed by Scheffran and Battaglini (2010), the pressure created by projected climate change seems likely to lead to increasing conflicts and their causalities. Sutton et al. (2010) suggest that projected climate change effects could cause civil wars in Africa by the 2030s (warming at this time would likely be below $1.5^{\circ} \mathrm{C}$ above pre-industrial).

Finally, Dronin and Kirilenko (2010) show that the existing administrative and institutional, as well as physical infrastructure in Russia will likely cause large problems for maintaining national food security and has historically contributed to famine in periods of drought. In Australia, (Steffen et al. 2010) show producers and industries operate from a long experience of coping with highly variable climate, but identified two climatic features that the sector is highly vulnerable to: abrupt climate shifts and intensifying droughts (see Risbey 2010). They point to the adaptive capacity of producers and industry as an important factor in determining what may be dangerous changes and argue that this sector has shown high adaptive capacity in the past and is beginning to adapt to changed climate variability now.

The IPCC AR4 assessment indicated that food production at the global level will probably be sufficient to feed the growing world population in the coming decades taking into account the projected effects of climate change. Observed negative effects of climate change on crop production in some regions (Auffhammer et al. 2006; Lobell and Field 2007) and new assessments of projections and uncertainties in relation to the role of $\mathrm{CO}_{2}$ fertilization indicate a risk that global food production could be under more pressure from climate change than previously estimated (Lobell and Field 2008; Leakey 2009; Nelson et al. 2009; Rost et al. 2009; Schlenker and Roberts 2009).

What emerges from the papers in this issue is the danger of a widespread deterioration of regional food security in the 21 st century under climate change for warming levels in the $1.5-2^{\circ} \mathrm{C}$ range. Many refer to the low adaptive capacity in some regions. Indeed, the most salient picture emerging from the papers in this issue on agriculture impacts is that highly challenging large-scale changes are required in regional specialization of food production, trade policies, development planning and water management for the regions discussed to have any chance of maintaining food security in the coming decades given global warming projections.

Arctic sea-ice loss, iconic species and loss of human cultures

Loss of Arctic sea ice and its consequential effects on icebased ecosystems and the Arctic marine environment are described by Johannessen and Miles (2010). An accelerating loss of Arctic summer sea ice and volume has been observed over the last 50 years amounting to a $50 \%$ decline (Serreze et al. 2007; Stroeve et al. 2007; Stroeve et al. 2008; Lindsay et al. 2009; Markus et al. 2009; Simmonds and Keay 2009), with losses occurring faster than predicted by models (Boe et al. 2009). Whereas the IPCC AR4 assessment indicated almost complete loss of late summer sea ice for some scenarios by the latter part of the $21 \mathrm{st}$ century, more recent projections indicate that this could occur as early as the 2030s (Wang and Overland 2009; Zhang 2010). Johannessen and Miles in (2010) estimate loss by the 2050s, but in any event by the latter half of the 21st century (Boe et al. 2009).

The consequences for Arctic sea ice-based systems and species are serious (Johannessen and Miles 2010) with increasing loss of summer sea-ice extent and volume likely to push polar bears, walrus, some Arctic sea birds and seals to extinction. The IPCC AR4 indicated that the Polar bear 
(Ursus maritimus) faces a high risk of extinction with global warming in the range $2.5-3.0^{\circ} \mathrm{C}$ above pre-industrial based in the model projections then available, which projected a multi-model mean $62 \%$ (range 40-100\%) loss of Arctic summer ice extent (Fischlin et al. 2007). With such losses projected now to occur at substantially lower temperatures (ca $1.5-2.0^{\circ} \mathrm{C}$ ), the extinction risk for this iconic species appears to be very high within the next half century. Detailed population-based observations (Schliebe et al. 2008; Stirling et al. 2008; Regehr et al. 2010; Rode et al. 2010) and projections (Durner et al. 2009; Hunter et al. 2010) confirm this inference.

Loss of unique and vulnerable polar communities was recognized as a key vulnerability in the IPCC AR4 (IPCC 2007; Schneider et al. 2007). Crowley (2010) makes a case for consideration of the loss of unique cultures, in this case the Inuit of the Arctic, as a basis for determining what is dangerous under Article 2: if it were to be accepted it could imply an even lower warming limit than $1.5^{\circ} \mathrm{C}$.

\section{Large-scale sea-level rise}

There have been significant developments in the projection of sea-level rise, which affects a number of the regions reviewed in this special issue. Recent studies (Rahmstorf 2007; Pfeffer et al. 2008; Rohling et al. 2008; Vermeer and Rahmstorf 2009) indicate that sea-level rise over the next century is likely to be significantly higher than the estimates in the IPCC AR4. ${ }^{7}$ The accelerating loss of ice from the Greenland and Antarctic ice sheets, which is occurring at a rate faster than previously predicted, was not able to be accounted for in the AR4 estimates of $20-60 \mathrm{~cm}$ above 1990 levels by the end of the 21 st century. New projections based on the observed relationship between sea level and temperature (Rahmstorf 2007; Vermeer and Rahmstorf 2009) estimate a sea-level rise of $0.5-1.4 \mathrm{~m}$ above 1990 levels by 2100 for a warming range of $2-6^{\circ} \mathrm{C}$ above preindustrial levels by 2100 .

Recent research on the relationship between Antarctic temperatures and global sea level over the last 520,000 years indicates that multi-metre increases in sea level over the next centuries from warming levels of only $2{ }^{\circ} \mathrm{C}$ are very likely due to the loss of ice from the ice sheets (Rohling et al. 2009). Evidence from a previous climatic warm period (119,000-124,000 years ago, when the climate warmed to around present levels and a bit higher)

\footnotetext{
7 The IPCC's Fourth Assessment Report estimated that global warming of $1.7-7^{\circ} \mathrm{C}$ above pre-industrial levels (without mitigation) would raise sea-level rise by $20-60 \mathrm{~cm}$ above 1990 levels by the end of the 21 st century. The accelerating loss of ice from the Greenland and Antarctic ice sheets, which is occurring at a rate much faster than previously predicted, was not able to be accounted for in the AR4 estimates.
}

shows that rapid sea-level rise caused by melting or disintegration of the ice sheets has occurred before. During that period, sea levels stood at 4-6 metres higher than at present, and the rates of sea-level rise averaged $1.6 \mathrm{~m} /$ century (Rohling et al. 2008). Recent examination of plausible melting and/or disintegration rates for the ice sheets suggest strongly that a metre or more is possible if not likely by 2100 and that two metres cannot be ruled out (Pfeffer et al. 2008). Sea-level rise of a few metres could result in widespread loss of coastal and deltaic areas such as Bangladesh, the Nile, Yangtze and Mekong Delta regions, as well as major losses for many small island countries.

In the nearer term, sea-level rise and increased water temperatures are projected to accelerate beach and coastal erosion and cause degradation of natural coastal defences, including mangroves and coral reefs. These would in turn impact negatively on water supply, fisheries productivity and tourism industries in many small island countries and other regions. Sea-level rise will exacerbate the impacts of more intense tropical cyclones predicted under global warming (IPCC 2007; Bender et al. 2010; Knutson et al. 2010) on infrastructure.

Sea-level rise of $0.5 \mathrm{~m}$ has been projected to result in the total number of people exposed to flooding risk in 136 port cities globally increasing by more than threefold to around 150 million people and the total value of assets exposed 8 could rise by more than a factor of 10 (Nicholls et al. 2008). The top 10 cities exposed in term of population by the 2070 s were Kolkata, Mumbai, Dhaka, Guangzhou, Ho Chi Minh City, Shanghai, Bangkok, Rangoon, Miami and Hai Phòng. On an asset base, the most vulnerable cities were found to be Miami, Guangdong, Greater New York, Kolkata, Shanghai, Mumbai, Tianjin, Tokyo, Hong Kong and Bangkok (Nicholls et al. 2008). Mirza (2010) reports that Bangladesh could lose $10 \%$ of its area due to a sea-level rise of $45 \mathrm{~cm}$, and other work has estimated a loss about $18 \%$ of land area for a $95 \mathrm{~cm}$ sea-level rise (World Bank 2000).

The risks linked to sea-level rise appear to qualify as a dangerous change and point towards warming levels significantly lower than $2^{\circ} \mathrm{C}$ above pre-industrial being needed to prevent dangerous interference with the climate system if this were defined as avoiding a sea-level rise significantly lower than a metre.

Finally, another large-scale risk to emerge strongly from this special issue and in particular the review by HoeghGuldberg (2010) is that of the likely massive loss of coral reefs, due to the effects of warming and an increased $\mathrm{CO}_{2}$ concentration acidifying the worlds oceans. Coral reefs

\footnotetext{
8 Whilst exposure to risk does not determine actual damage, it is a useful indication of the way in which risk is increasing with sea level rise and global warming as the world develops.
} 
provide vital resources for many small island states and are highly sensitive to both warming and ocean acidification due to increased $\mathrm{CO}_{2}$ concentrations.

High ocean temperatures have already started to trigger unprecedented mass coral bleaching events effecting entire reefs, regions and countries. The IPCC AR4 found that "Climate change is likely to heavily impact coral reefs, fisheries and other marine-based resources" (Mimura et al. 2007). With $1.5-2^{\circ} \mathrm{C}$ warming, widespread mortality of coral reefs was predicted (Fischlin et al. 2007). Since the IPCC AR4, scientific understanding of the risks to coral reefs has expanded substantially. Regionally, for example, projections based on IPCC AR4 climate model simulations indicate that severe thermal stress may become a biannual to annual event in the Eastern Caribbean by the 2020s or 2030s when global mean temperature is increased by about $1-1.5^{\circ} \mathrm{C}$ from pre-industrial levels (Donner et al. 2007).

The most significant findings, however, relate to the effect of ocean acidification (Hoegh-Guldberg 2010). As $\mathrm{CO}_{2}$ concentration in the atmosphere rises, the oceans absorb more $\mathrm{CO}_{2}$, increasing the acidity of the oceans. An increase in ocean acidity has already been reported by the IPCC (2007). Higher ocean acidity reduces the ability of coral species to sequester calcium, which is vitally required for growth and maintenance of coral reefs (Fischlin et al. 2007). Reduced reef calcification has been observed since 1990 in some regions (Cooper et al. 2008; De' ath et al. 2009; Tanzil et al. 2009). ${ }^{9}$ It has been estimated that corals around the world are likely to stop growing once atmospheric $\mathrm{CO}_{2}$ concentration climbs above about $450 \mathrm{ppm}$, and would start dissolving above 550 ppm $\mathrm{CO}_{2}$ (Cao and Caldeira 2008; Silverman et al. 2009). Negative effects on the reproductive cycle of corals are also predicted (Albright et al. 2010).

These and other considerations lead Hoegh-Guldberg (2010), and others (Donner 2009; Veron et al. 2009) to conclude that the survival of coral reefs implies a need to reduce $\mathrm{CO}_{2}$ concentration to $350 \mathrm{ppm}$ or below. The warming limit for the viability of reefs appears to be substantially lower than a $2^{\circ} \mathrm{C}$ global mean warming, possibly lower than $1.5^{\circ} \mathrm{C}$.

\section{Conclusions}

The examples from the literature described above can be used to define levels of climate change that would constitute dangerous anthropogenic interference with the climate system under Article 2 of the UNFCCC. In the eyes of

\footnotetext{
9 Although some corals might be able to adapt to temperature changes within certain limits, there is one recent study showing that this ability might be reduced under high $\mathrm{CO}_{2}$ conditions: $\mathrm{CO}_{2}$ could act as a bleaching agent and even lower thermal bleaching thresholds (Anthony et al. 2008).
}

many, they imply the need to limit both global mean warming and $\mathrm{CO}_{2}$ concentration to levels, respectively, substantially lower than $2^{\circ} \mathrm{C}$ and likely below $1.5^{\circ} \mathrm{C}$ in the
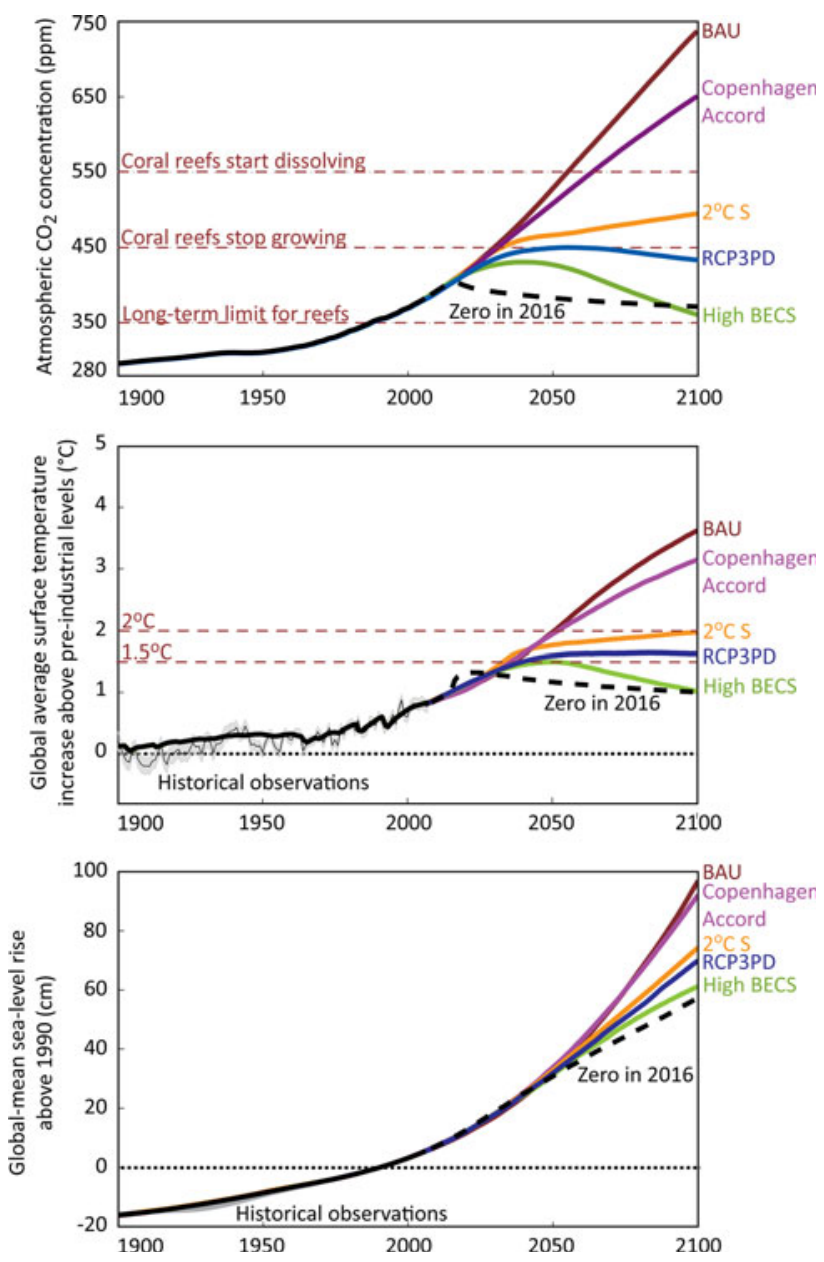

Fig. 1 Illustration of the effect of the current emissions reduction proposals under the Copenhagen Accord. Besides the pathways representing a business-as-usual scenario (BAU very close to SRES A1B, Nakicenovic et al. 2000) and the estimated emissions based on the Copenhagen Accord proposals (Rogelj et al. 2010a; Rogelj et al. 2010b), four low-emission pathways are shown. The black dashed line indicates the expected temperature projections if all global emissions (greenhouse gases and aerosols) would become zero in 2016. It therefore illustrates the global warming commitment due to emissions until 2015. The green line represents a scenario that reaches negative $\mathrm{CO}_{2}$ emissions shortly after 2050, by implementing largescale biomass energy systems combined with carbon capture and storage (BECS) at the high end of the potential range found in literature (e.g., Azar et al. 2006; van Vuuren et al. 2008; Knopf et al. 2010). RCP3PD (van Vuuren et al. 2008) is an illustrative lowemissions scenario technically and economically feasible at modest overall costs and which is to be used in the IPCC Fifth Assessment Report (AR5) as the lowest reference concentration profile. Finally, $2^{\circ} \mathrm{C} \mathrm{S}$ represents an illustrative example of an emission pathway aimed at stabilizing global warming at $2{ }^{\circ} \mathrm{C}$ above pre-industrial. Projections for $\mathrm{CO}_{2}$ and temperature change follow models and method of Meinshausen et al. (2009). Sea-level rise projections follow models and method of Rahmstorf (2007). The median projections from these Monte-Carlo setups are shown here 
longer term and below present levels of $\mathrm{CO}_{2}$ concentration, likely below $350 \mathrm{ppm}$.

The emission pledges made under Copenhagen Accord are estimated to result in a warming of $3.3^{\circ} \mathrm{C}$ above preindustrial within the 21 st century (Rogelj et al. 2010a, b), substantially above the levels of warming identified here as possibly dangerous. In relation to the $\mathrm{CO}_{2}$ concentration levels identified here as potentially dangerous, the Copenhagen Accord pledges imply that a $\mathrm{CO}_{2}$ concentration of $450 \mathrm{ppm}$ could be reached as early as the 2030s (Rogelj et al. 2010a, b). $\mathrm{CO}_{2}$ concentration was about $278 \mathrm{ppm}$ in pre-industrial times (mid-19th century) and as of the end of 2009 was around 387 ppmv $^{10}$ (Friedlingstein et al. 2010), above the $350 \mathrm{ppm}$ level that may be appropriated for long-term coral reef survival. See Fig. 1 for an overview of scenario projections.

The emission pledges made under the Copenhagen Accord is, in view of the examples provided and the evidence collected in this special issue, insufficient to meet the terms of Article 2 of preventing dangerous climate change. More work needs to be done to further define and operationalize Article 2, but we need to accept that danger necessarily has a subjective dimension and that its definition requires judgment and precaution.

Acknowledgments The papers in this special issue stem in large part from work begun at a Symposium on "Key vulnerable regions and climate change", 27-30 October 2004, in Beijing at the Institute of Atmospheric Physics, Beijing University/The Nansen-Zhu International Research Centre, organized by the European Climate Forum and sponsored by Munich Re, the Heinrich Böll Foundation, Deutsche Gesellschaft fur Technische Zusammenarbeit (GTZ), and the German Federal Environmental Ministry (BMU). The Organizing Committee of the symposium was formed by Bill Hare (PIK), Martin Welp (University of Applied Sciences in Eberswalde/ECF), Huijun Wang (Institute of Atmospheric Physics, Beijing University/The NansenZhu International Research Centre, Beijing), Jiahua Pan (Research Centre for Sustainable Development, Chinese Academy of Social Sciences, Beijing), and Ola Johannessen (Nansen Remote and Environmental Sensing Centre, Bergen, Norway). We thank all authors for their contributions, updates and patience during the editorial process of this special issue. We also acknowledge comments made by a large numbers of reviewers. Technical editing was supported, at PIK, by Felix Fallasch, Vera Tekken and Sabine Lütkemeier.

\section{References}

Albright R, Mason B, Miller M, Langdon C (2010) Ocean acidification compromises recruitment success of the threatened Caribbean coral Acropora palmata. Proc Natl Acad Sci 107(47):20400-20404. doi:10.1073/pnas.1007273107

Alkemade R, Bakkenes M, Eickhout B (2010) Towards a general relationship between climate change and biodiversity: an example for plant species in Europe. Reg Environ Change. doi: 10.1007/s10113-010-0161-1

$\overline{10 \mathrm{ftp} / / / \mathrm{ftp} . \mathrm{cm}} \mathrm{dl}$.noaa.gov/ccg/co2/trends/co2_annmean_mlo.txt.
Anthony KR, Kline DI, Diaz-Pulido G, Dove S, Hoegh-Guldberg O (2008) Ocean acidification causes bleaching and productivity loss in coral reef builders. Proc Natl Acad Sci USA 105:17442-17446. doi:10.1007/s10113-010-0189-2

Auffhammer M, Ramanathan V, Vincent JR (2006) Integrated model shows that atmospheric brown clouds and greenhouse gases have reduced rice harvests in India. Proc Natl Acad Sci 103(52):19668-19672. doi:10.1073/pnas.0609584104

Azar C, Lindgren K, Larson E, Möllersten K, Yand J (2006) Carbon capture and storage from fossil fuels and biomass-Costs and potential role in stabilizing the atmosphere. Clim Change 74(1-3):47-79

Barnett J (2010) Dangerous climate change in the Pacific Islands: food production and food security. Reg Environ Change. doi: 10.1007/s10113-010-0160-2

Bates NR, Mathis JT, Cooper LW (2009) Ocean acidification and biologically induced seasonality of carbonate mineral saturation states in the western Arctic Ocean. J Geophys Res-Oceans 114:C11007. doi:10.1029/2008jc004862

Battisti DS, Naylor RL (2009) Historical warnings of future food insecurity with unprecedented seasonal heat. Science 323(5911):240-244. doi:10.1126/science.1164363

Ben Mohamed A (2010) Climate change risks in Sahelian Africa. Reg Environ Change. doi:10.1007/s10113-010-0172-y

Bender MA, Knutson TR, Tuleya RE, Sirutis JJ, Vecchi GA, Garner ST, Held IM (2010) Modelled impact of anthropogenic warming on the frequency of intense Atlantic hurricanes. Science 327(5964):454-458. doi:10.1126/science.1180568

Bindi M, Olesen JE (2010) The responses of agriculture in Europe to climate change. Reg Environ Change. doi:10.1007/s10113010-0173-X

Boe J, Hall A, Qu X (2009) September sea-ice cover in the Arctic Ocean projected to vanish by 2100 . Nat Geosci 2(5):341-343

Burke MB, Lobell DB, Guarino L (2009) Shifts in African crop climates by 2050, and the implications for crop improvement and genetic resources conservation. Glob Environ Change 19(3):317-325. doi:10.1016/j.gloenvcha.2009.04.003

Cao L, Caldeira K (2008) Atmospheric $\mathrm{CO}_{2}$ stabilization and ocean acidification. Geophys Res Lett 35:L19609

Cao L, Caldeira K, Jain AK (2007) Effects of carbon dioxide and climate change on ocean acidification and carbonate mineral saturation. Geophys Res Lett 34(5):L05607

Chevallier P, Pouyaud B, Suarez W, Condom T (2010) Climate change threats to environment in the tropical Andes: glaciers and water resources. Reg Environ Change. doi:10.1007/s10113-0100177-6

Comeau S, Gorsky G, Jeffree R, Teyssie JL, Gattuso JP (2009) Impact of ocean acidification on a key arctic pelagic mollusc (Limacina helicina). Biogeosciences 6(9):1877-1882

Cooper TF, De'Ath G, Fabricius KE, Lough JM (2008) Declining coral calcification in massive Porites in two nearshore regions of the northern Great Barrier Reef. Glob Chang Biol 14(3):529538. doi:10.1111/j.1365-2486.2007.01520.x

Crawley A, Kline DI, Dunn S, Anthony K, Dove S (2010) The effect of ocean acidification on symbiont photorespiration and productivity in Acropora formosa. Glob Chang Biol 16(2):851-863. doi:10.1111/j.1365-2486.2009.01943.x

Crowley P (2010) Interpreting 'dangerous' in the United Nations framework convention on climate change and the human rights of Inuit. Reg Environ Change. doi:10.1007/s10113-010-0188-3

De'ath G, Lough JM, Fabricius KE (2009) Declining coral calcification on the Great Barrier Reef. Science 323:116-119

Denman KL, Brasseur G, Chidthaisong A, Ciais P, Cox PM, Dickinson RE, Hauglustaine D, Heinze C, Holland E, Jacob D, Lohmann U, Ramachandran S, da Silva Dias PL, Wofsy SC, Zhang X (2007) Couplings between changes in the climate 
system and biogeochemistry. In: Solomon S, Qin D, Manning M et al (eds) Climate change 2007: the physical science basis. Contribution of working group I to the fourth assessment report of the intergovernmental panel on climate change. Cambridge University Press, Cambridge, pp 499-587

Donner SD (2009) Coping with commitment: projected thermal stress on coral reefs under different future scenarios. PLoS ONE 4(6): 55712

Donner SD, Knutson TR, Oppenheimer M (2007) Model-based assessment of the role of human-induced climate change in the 2005 Caribbean coral bleaching event. Proc Natl Acad Sci USA 104(13):5483-5488

Dronin N, Kirilenko A (2010) Climate change, food stress, and security in Russia. Reg Environ Change. doi:10.1007/s10113010-0165-x

Durner GM, Douglas DC, Nielson RM, Amstrup SC, McDonald TL, Stirling I, Mauritzen M, Born EW, Wiig $\varnothing$, DeWeaver E, Serreze MC, Belikov SE, Holland MM, Maslanik J, Aars J, Bailey DA, Derocher AE (2009) Predicting 21st-century polar bear habitat distribution from global climate models. Ecol Monogr 79(1):25-58. doi:10.1890/07-2089.1

ENDS (2005) EU leaders back 2020 greenhouse gas target. ENDS daily, 23 March 2005

Environment Council of the European Union (2005) Climate change: medium and longer term emission reduction strategies, including targets. Council conclusions. Eur Com, Brussels

European Community (1996) Climate change-Council conclusions 8518/96 (Presse 188-G) 25/26. VI.96

European Union (2005) Council of the European Union, presidency conclusions-Brussels, 22 and 23 March 2005 IV. Climate change. Eur Com, Brussels

Feely RA, Doney SC, Cooley SR (2009) Ocean acidification: present conditions and future changes in a high- $\mathrm{CO}_{2}$ world. Oceanography 22(4):36-47

Fischlin A, Midgley GF, Price JT, Leemans R, Gopal B, Turley C, Rounsevell MDA, Dube OP, Tarazona J, Velichko AA (2007) Ecosystems, their properties, goods, and services. In: Parry ML, Canziani OF, Palutikof JP, van der Linden PJ, Hanson CE (eds) Climate change 2007: impacts, adaptation and vulnerability. Contribution of working group II to the fourth assessment report of the intergovernmental panel on climate change. Cambridge University Press, Cambridge, pp 211-272. doi:10.1007/s10113010-0191-8

Friedlingstein P, Solomon S (2005) Contributions of past and present human generations to committed warming caused by carbon dioxide. PNAS 102(31):10832-10836

Friedlingstein P, Houghton RA, Marland G, Hackler J, Boden TA, Conway TJ, Canadell JG, Raupach MR, Ciais P, Le Quere C (2010) Update on $\mathrm{CO}_{2}$ emissions. Nat Geosci advance online publication

G8 (2009) Chair's summary, L'Aquila, 10 July 2009. G8, L'Aquila, Italy. http://www.g8italia2009.it/G8/Home/G8-G8_Layout_ locale-1199882116809_Atti.htm

GU WB (2003) Climate protection strategies for the 21st century: Kyoto and beyond. WBGU-German Advisory Council on GLobal Change, Berlin

Hansen J, Sato M, Kharecha P, Russell G, Lea DW, Siddall M (2007) Climate change and trace gases. Philos Transact A Math Phys Eng Sci 365(1856):1925-1954

Hansen J, Sato M, Kharecha P, Beerling D, Berner R, MassonDelmotte V, Pagani M, Raymo M, Royer DL, Zachos JC (2008) Target atmospheric $\mathrm{CO}_{2}$ : where should humanity aim? Open Atmos Sci J 2:217-231

Hare B, Meinshausen M (2006) How much warming are we committed to and how much can be avoided? Clim Change 18:1-39
Hendriks IE, Duarte CM, Alvarez M (2010) Vulnerability of marine biodiversity to ocean acidification: a meta-analysis. Estuar Coast Shelf S 86(2):157-164. doi:10.1016/j.ecss.2009.11.022

Hoegh-Guldberg O (2010) Coral reef ecosystems and anthropogenic climate change. Reg Environ Change. doi:10.1007/s10113010-0189-2

Hughes L (2010) Climate change and Australia: key vulnerable regions. Reg Environ Change. doi:10.1007/s10113-010-0158-9

Hunter CM, Caswell H, Runge MC, Regehr EV, Amstrup SC, Stirling I (2010) Climate change threatens polar bear populations: a stochastic demographic analysis. Ecology 91(10):2883-2897. doi:10.1890/09-1641.1

Iglesias A, Mougou R, Moneo M, Quiroga S (2010) Towards adaptation of agriculture to climate change in the Mediterranean. Reg Environ Change. doi:10.1007/s10113-010-0187-4

IPCC, 1996: Climate Change 1995: The Science of Climate Change. Contribution of Working Group I to the Second Assessment Report of the Intergovernmental Panel on Climate Change, J.T. Houghton, L.G. Meiro Filho, B.A. Callander, N. Harris, A. Kattenburg and K. Maskell, Eds., Cambridge University Press, Cambridge

IPCC, 2007: Climate Change 2007: Synthesis Report. Contribution of Working Groups I, II, and III to the Fourth Assessment Report of the Intergovernmental Panel on Climate Change, Core Writing Team, R.K. Pachauri and A. Reisinger, Eds., IPCC, Geneva

Jaeger CC, Jaeger J (2010) Three views of two degrees. Reg Environ Change. doi:10.1007/s10113-010-0190-9

Jain AK, Bach W (1994) The effectiveness of measures to reduce the man-made greenhouse effect. The application of a climate-policy model. Theor Appl Climatol 49(2):103-118

Johannessen OM, Miles MW (2010) Critical vulnerabilities of marine and sea ice-based ecosystems in the high Arctic. Reg Environ Change. doi:10.1007/s10113-010-0186-5

Kittel TGF, Baker BB, Higgins JV, Haney JC (2010) Climate vulnerability of ecosystems and landscapes on Alaska's North Slope. Reg Environ Change. doi:10.1007/s10113-010-0180-y

Klein JA, Harte J, Zhao XQ (2004) Experimental warming cause's large and rapid species loss, dampened by simulated grazing, on the Tibetan Plateau. Ecol Lett 7(12):1170-1179

Knopf B, Edenhofer O, Flachsland C, Kok MTJ, Lotze-Campen H, Luderer G, Popp A, Vuuren DPV (2010) Managing the LowCarbon Transition-From model results to policies. Energy $\mathbf{J}$ (Special Issue) 31:223-245

Knutson TR, McBride JL, Chan J, Emanuel K, Holland G, Landsea C, Held I, Kossin JP, Srivastava AK, Sugi M (2010) Tropical cyclones and climate change. Nat Geosci 3(3):157-163. http://www.nature.com/ngeo/journal/v3/n3/suppinfo/ ngeo779_S1.html

Kriegler E, Hall JW, Held H, Dawson R, Schellnhuber HJ (2009) Imprecise probability assessment of tipping points in the climate system. Proc Natl Acad Sci USA 106(13):5041-5046. doi: 10.1073/pnas.0809117106

Lal M (2010) Implications of climate change in sustained agricultural productivity in South Asia. Reg Environ Change. doi:10.1007/ s10113-010-0166-9

Leakey ADB (2009) Rising atmospheric carbon dioxide concentration and the future of C4 crops for food and fuel. Proc R Soc Lond B Biol Sci 276(1666):2333-2343

Lenton TM, Myerscough RJ, Marsh R, Livina VN, Price AR, Cox SJ (2009) Using GENIE to study a tipping point in the climate system. Philos Transact A Math Phys Eng Sci 367(1890):871884. doi:10.1098/rsta.2008.0171

Lindsay RW, Zhang J, Schweiger A, Steele M, Stern H (2009) Arctic sea ice retreat in 2007 follows thinning trend. J Clim 22(1):165-176

Lobell DB, Field CB (2007) Global scale climate-crop yield relationships and the impacts of recent warming. Environ Res Lett 2(1):014002 
Lobell DB, Field CB (2008) Estimation of the carbon dioxide $\left(\mathrm{CO}_{2}\right)$ fertilization effect using growth rate anomalies of $\mathrm{CO}_{2}$ and crop yields since 1961. Glob Chang Biol 14(1):39-45. doi:10.1111/ j.1365-2486.2007.01476.x

Major Economies Forum (2009) Declaration of the leaders of the major economies forum on energy and climate, 9 July 2009. Major economies forum on energy and climate, L'Aquila, Italy. http://www.majoreconomiesforum.org/past-meetings/the-firstleaders-meeting.html

Malhi Y, Aragão LEOC, Galbraith D, Huntingford C, Fisher R, Zelazowski P, Sitch S, McSweeney C, Meir P (2009) Exploring the likelihood and mechanism of a climate-change-induced dieback of the Amazon rainforest. Proc Natl Acad Sci USA 106:20610-20615. doi:10.1073/pnas.0804619106

Manzello DP (2010) Ocean acidification hot spots: spatiotemporal dynamics of the seawater $\mathrm{CO}_{2}$ system of eastern Pacific coral reefs. Limnol Oceanogr 55(1):239-248

Markus T, Stroeve JC, Miller J (2009) Recent changes in Arctic sea ice melt onset, freezeup, and melt season length. J Geophys Res 114(C12):C12024. doi:10.1029/2009jc005436

McClintock JB, Angus RA, Mcdonald MR, Amsler CD (2009) Ocean acidification and calcified Antarctic seafloor microorganisms: the perfect storm. Integr Comp Biol 49:E269-E269

McNeil BI, Matear RJ (2007) Climate change feedbacks on future oceanic acidification. Tellus B 59(2):191-198. doi:10.1111/ j.1600-0889.2006.00241.x

McNeil BI, Matear RJ (2008) Southern ocean acidification: a tipping point at 450-ppm atmospheric $\mathrm{CO}_{2}$. Proc Natl Acad Sci USA 105(48):18860-18864. doi:10.1073/pnas.0806318105

McNeil BI, Tagliabue A, Sweeney C (2010) A multi-decadal delay in the onset of corrosive 'acidified' waters in the Ross Sea of Antarctica due to strong air-sea $\mathrm{CO}_{2}$ disequilibrium. Geophys Res Lett 37(19):L19607. doi:10.1029/2010g1044597

Meehl GA, Stocker TF, Collins WD, Friedlingstein P, Gaye AT, Gregory JM, Kitoh A, Knutti R, Murphy JM, Noda A (2007) Global Clim Proj. In: Solomon S, Qin D, Manning M et al (eds) Climate change 2007: the physical science basis. Contribution of working group I to the fourth assessment report of the intergovernmental panel on climate change. Cambridge University Press, Cambridge, pp 747-846

Meinshausen M, Meinshausen N, Hare W, Raper SCB, Frieler K, Knutti R, Frame DJ, Allen MR (2009) Greenhouse-gas emission targets for limiting global warming to $2^{\circ} \mathrm{C}$. Nature $458: 1158-1162$

Midgley GF, Thuiller W (2010) Potential responses of terrestrial biodiversity in Southern Africa to anthropogenic climate change. Reg Environ Change. doi:10.1007/s10113-010-0191-8

Mimura N, Nurse L, McLean RF, Agard J, Briguglio L, Lefale P, Payet R, Sem G (2007) Small islands. In: Parry ML, Canziani OF, Palutikof JP, Van der Linden PJ, Hanson CE (eds) Climate change 2007: impacts, adaptation and vulnerability. Contribution of working group II to the fourth assessment report of the intergovernmental panel on climate change. Cambridge University Press, Cambridge, pp 687-716

Mirza MMQ (2010) Climate change, flooding in South Asia and implications. Reg Environ Change. doi:10.1007/s10113-0100184-7

Mougou R, Mansour M, Iglesias A, Chebbi RZ, Battaglini A (2010) Climate change and agricultural vulnerability: a case study of rain-fed wheat in Kairouan, Central Tunisia. Reg Environ Change. doi:10.1007/s10113-010-0179-4

Moy AD, Howard WR, Bray SG, Trull TW (2009) Reduced calcification in modern Southern Ocean planktonic foraminifera. Nat Geosci 2(4):276-280. doi:10.1038/Ngeo460

Nakicenovic N, Swart R (eds) (2000) Emissions scenarios. 2000 special report of the intergovernmental panel on climate change. Cambridge University Press, Cambridge
Nelson GC, Rosegrant MW, Koo J, Robertson R, Sulser T, Zhu T, Ringler C, Msangi S, Palazzo A, Batka M, Magalhaes M, Valmonte-Santos R, Ewing M, Lee D (2009) Climate change: impact on agriculture and costs of adaptation. International Food Policy Research Institute (IFPRI). doi:10.2499/0896295354

Ni J (2010) Impacts of climate change on Chinese ecosystems: key vulnerable regions and potential thresholds. Reg Environ Change. doi:10.1007/s10113-010-0170-0

Ni J, Sykes MT, Prentice IC, Cramer W (2000) Modelling the vegetation of China using the process-based equilibrium terrestrial biosphere model BIOME3. Glob Ecol Biogeogr 9(6):463-479

Nicholls R, Hanson S, Herweijer C, Patmore N, Hallegatte S, CorfeeMorlot J, Château J, Muir-Wood R (2008) Ranking port cities with high exposure and vulnerability to climate extremes. OECD environment working papers, vol 1. OECD environment working papers, Paris. doi:10.1787/011766488208. http://oberon. sourceoecd.org/vl=386507/cl=24/nw=1/rpsv/workingpapers/ 19970900/wp_5kzssgshj742.htm

Nordhaus WD (1977) Economic-growth and climate-Carbon-dioxide problem. Am Econ Rev 67(1):341-346

Oppenheimer M, Petsonk A (2005) Article 2 of the UNFCCC: historical origins, recent interpretations. Clim Change 73(3): 195-226

Orr JC, Fabry VJ, Aumont O, Bopp L, Doney SC, Feely RA, Gnanadesikan A, Gruber N, Ishida A, Joos F, Key RM, Lindsay K, Maier-Reimer E, Matear R, Monfray P, Mouchet A, Najjar RG, Plattner G-K, Rodgers KB, Sabine CL, Sarmiento JL, Schlitzer R, Slater RD, Totterdell IJ, Weirig M-F, Yamanaka Y, Yool A (2005) Anthropogenic ocean acidification over the twenty-first century and its impact on calcifying organisms. Nature 437(7059):681-686

Penny S, Roe GH, Battisti DS (2010) The source of the midwinter suppression in storminess over the North Pacific. J Clim 23(3):634-648. doi:10.1175/2009JCLI2904.1

Pfeffer WT, Harper JT, O'Neel S (2008) Kinematic constraints on glacier contributions to 21st-century sea-level rise. Science 321(5894):1340-1343. doi:10.1126/science.1159099

Potter TD (1986) Advisory group on greenhouse gases established jointly by WMO, UNEP, and ICSU. Environ Conserv 13(04): 365. doi:10.1017/S0376892900035505

Rahmstorf S (2007) A semi-empirical approach to projecting future sea-level rise. Science 315(5810):368-370. doi:10.1126/science. 1135456

Regehr EV, Hunter CM, Caswell H, Amstrup SC, Stirling I (2010) Survival and breeding of polar bears in the southern Beaufort Sea in relation to sea ice. J Anim Ecol 79(1):117-127. doi: 10.1111/j.1365-2656.2009.01603.x

Rijsberman F, Swart R (eds) (1990) Targets and indicators of climate change. Report of working group II of the advisory group on greenhouse gases. Stockholm Environmental Institute, Stockholm

Risbey JS (2010) Dangerous climate change and water resources in Australia. Reg Environ Change. doi:10.1007/s10113-010-0176-7

Rode KD, Amstrup SC, Regehr EV (2010) Reduced body size and cub recruitment in polar bears associated with sea ice decline. Ecol Appl 20(3):768-782. doi:10.1890/08-1036.1

Rogelj J, Chen C, Nabel J, Macey K, Hare W, Schaeffer M, Markmann K, Höhne N, Krogh Anderson K, Meinshausen M (2010a) Analysis of the Copenhagen accord pledges and its global climatic impacts' a snapshot of dissonant ambitions. Environ Res Lett 5(3):034013

Rogelj J, Nabel J, Chen C, Hare W, Markmann K, Meinshausen M, Schaeffer M, Macey K, Höhne N (2010b) Copenhagen accord pledges are paltry. Nature 464(7292):1126-1128

Rohling EJ, Grant K, Hemleben C, Siddall M, Hoogakker BAA, Bolshaw M, Kucera M (2008) High rates of sea-level rise during the last interglacial period. Nat Geosci 1(1):38-42 
Rohling EJ, Grant K, Bolshaw M, Roberts AP, Siddall M, Hemleben C, Kucera M (2009) Antarctic temperature and global sea level closely coupled over the past five glacial cycles. Nat Geosci 2(7):500-504

Rost S, Gerten D, Hoff H, Lucht W, Falkenmark M, Rockström J (2009) Global potential to increase crop production through water management in rain fed agriculture. Environ Res Lett 4(4):22

Scheffran J, Battaglini A (2010) Climate and conflicts: the security risks of global warming. Reg Environ Change. doi:10.1007/ s10113-010-0175-8

Schlenker W, Lobell DB (2010) Robust negative impacts of climate change on African agriculture. Environ Res Lett 1:014010

Schlenker W, Roberts MJ (2009) Nonlinear temperature effects indicate severe damages to U.S. crop yields under climate change. Proc Natl Acad Sci USA 106(37):15594-15598. doi: 10.1073/pnas.0906865106

Schliebe S, Rode KD, Gleason JS, Wilder J, Proffitt K, Evans TJ, Miller S (2008) Effects of sea ice extent and food availability on spatial and temporal distribution of polar bears during the fall open-water period in the Southern Beaufort Sea. Polar Biolo 31(8):999-1010

Schneider SH, Semenov S, Patwardhan A, Burton I, Magadza CHD, Oppenheimer M, Pittock AB, Rahman A, Smith JB, Suarez A (2007) Assessing key vulnerabilities and the risk from climate change. In: Parry ML, Canziani OF, Palutikof JP, van der Linden PJ, Hanson CE (eds) Climate change 2007: impacts, adaptation and vulnerability. Contribution of working group II to the fourth assessment report of the intergovernmental panel on climate change. Cambridge University Press, Cambridge, pp 779-810

Serreze MC, Holland MM, Stroeve J (2007) Perspectives on the Arctic's shrinking sea-ice cover. Science 315(5818):1533-1536. doi:10.1126/science.1139426

Shi DL, Xu Y, Hopkinson BM, Morel FMM (2010) Effect of ocean acidification on iron availability to marine phytoplankton. Science 327(5966):676-679. doi:10.1126/science.1183517

Shrestha AB, Aryal R (2010) Climate change in Nepal and its impact on Himalayan glaciers. Reg Environ Change. doi:10.1007/ s10113-010-0174-9

Silverman J, Lazar B, Cao L, Caldeira K, Erez J (2009) Coral reefs may start dissolving when atmospheric $\mathrm{CO}_{2}$ doubles. Geophys Res Lett 36:L05606

Simmonds I, Keay K (2009) Extraordinary September Arctic sea ice reductions and their relationships with storm behaviour over 1979-2008. Geophys Res Lett 36. doi:10.1029/2009g1039810

Sissoko K, van Keulen H, Verhagen J, Tekken V, Battaglini A (2010) Agriculture, livelihoods and climate change in the West African Sahel. Reg Environ Change. doi:10.1007/s10113-010-0164-y

Steffen W, Sims J, Walcott J, Laughlin G (2010) Australian agriculture: coping with dangerous climate change. Reg Environ Change. doi:10.1007/s10113-010-0178-5

Steinacher M, Joos F, Frölicher TL, Plattner GK, Doney SC (2009) Imminent ocean acidification in the Arctic projected with the NCAR global coupled carbon cycle-climate model. Biogeosciences 6(4):515-533

Stirling I, Richardson E, Thiemann GW, Derocher AE (2008) Unusual predation attempts of polar bears on ringed seals in the southern Beaufort Sea: possible significance of changing spring ice conditions. Arctic 61(1):14-22

Stroeve J, Holland MM, Meier W, Scambos T, Serreze M (2007) Arctic sea ice decline: faster than forecast. Geophys Res Lett 34(9):1-5. doi:10.1029/2007GL029703

Stroeve J, Serreze M, Drobot S, Gearheard S, Holland M, Maslanik J, Meier W, Scambos T (2008) Arctic sea ice extent plummets in 2007. EOS Trans Am Geophys Union 81:13-14
Sutton AE, Dohn J, Loyd K, Tredennick A, Bucini G, Solorzano A, Prihodko L, Hanan NP (2010) Does warming increase the risk of civil war in Africa? Proc Nat Acad Sci 107(25):E102-E102

Tanzil J, Brown B, Tudhope A, Dunne R (2009) Decline in skeletal growth of the coral Porites lutea from the Andaman Sea, South Thailand, between 1984 and 2005. Coral Reefs 28(2):519-528

Tao F, Zhang Z (in press) Impacts of climate change as a function of global mean temperature: maize productivity and water use in China. Clim Change

Tao FL, Yokozawa M, Liu J, Zhang Z (2009) Climate change, land use change, and China's food security in the twenty-first century: an integrated perspective. Clim Change 93(3-4):433-445. doi: 10.1007/s10113-010-0159-8

Tao F, Zhang Z, Yokozawa M (2010) Dangerous levels of climate change for agricultural production in China. Reg Environ Change. doi:10.1007/s10113-010-0159-8

UNFCCC (1992) The united nations framework convention on climate change. http://unfccc.int/essential_background/ convention/items/2627.php. Accessed 13 Aug 2009

van Vuuren DP, Meinshausen M, Plattner G-K, Joos F, Strassmann KM, Smith SJ, Wigley TML, Raper SCB, Riahi K, de la Chesnaye F, den Elzen MGJ, Fujino J, Jiang K, Nakicenovic N, Paltsev S, Reilly JM (2008) Temperature increase of 21st century mitigation scenarios. Proc Natl Acad Sci USA 105(40): $15258-15262$

Verheyen R (2007) The climate change regime after Montreal: Article 2 of the UN framework convention on climate change revisited. In: Etty T, Somsen H (eds) Yearbook of European environmental law, vol 7. Oxford University Press, Oxford, p 234

Vermeer M, Rahmstorf S (2009) Global sea level linked to global temperature. Proc Natl Acad Sci USA 106(51):21527-21532. doi:10.1073/pnas.0907765106

Veron JEN, Hoegh-Guldberg O, Lenton TM, Lough JM, Obura DO, Pearce-Kelly P, Sheppard CRC, Spalding M, Stafford-Smith MG, Rogers AD (2009) The coral reef crisis: the critical importance of $<350 \mathrm{ppm} \mathrm{CO}_{2}$. Mar Pollut Bull 58(10):14281436. doi:10.1016/j.marpolbul.2009.09.009

Wang M, Overland JE (2009) A sea ice free summer Arctic within 30 years? Geophys Res Lett 36:L07502. doi:10.1029/2009 g1037820

WBGU (1995) Scenario for the derivation of global $\mathrm{CO}_{2}$ reduction targets and implementation strategies. WBGU-German Advisory Council on Global Change, Bremerhaven

WBGU (2006) The future oceans-warming up, rising high, turning sour: special report. Wissenschaftlicher Beirat der Bundesregierung Globale Umweltveränderungen (WBGU)—German Advisory Council on Global Change, Berlin. http://www.wbgu.de

Wigley TML (2005) The climate change commitment. Science 307(5716):1766-1769. doi:10.1126/science.1103934

World Bank (2000) Bangladesh climate change and sustainable development, vol 21104-BD. Dhaka, Bangladesh

Xiong W, Lin E, Ju H, Xu Y (2007a) Climate change and critical thresholds in China's food security. Clim Change V81(2):205-221

Xiong W, Matthews R, Holman I, Lin E, Xu Y (2007b) Modelling China's potential maize production at regional scale under climate change. Clim Change 85(3):433-451

Yao F, Xu Y, Lin E, Yokozawa M, Zhang J (2007) Assessing the impacts of climate change on rice yields in the main rice areas of China. Clim Change V80(3):395-409

Zhang X (2010) Sensitivity of arctic summer sea ice coverage to global warming forcing: towards reducing uncertainty in arctic climate change projections. Tellus A 62(3):220-227

Zhao MS, Neilson RP, Yan XD, Dong WJ (2002) Modelling the vegetation of China under changing climate. Acta Geographica Sinica 57:28-38 